\title{
Effect of Rhizobium and Boron Application on Yield of Mung Bean, Nutrients Uptake and Fertility Status Grown in Red Soils of Mirzapur
}

\author{
P. K. Mishra ${ }^{1 *}$, Surendra Singh ${ }^{1}$, R. Verma ${ }^{2}$ and S. S. Verma \\ ${ }^{1}$ Department of Soil Science and Agricultural Chemistry, \\ Institute of Agricultural Sciences, BHU, Varanasi (U.P.), India \\ ${ }^{2}$ Department of Soil Science and Agricultural Chemistry, \\ SKN College of Agriculture, SKNAU, Jobner (Rajasthan), India \\ *Corresponding author
}

\author{
A B S T R A C T
}

\begin{tabular}{|c|}
\hline Keywords \\
\hline $\begin{array}{l}\text { Red soil, Boron, } \\
\text { Rhizobium and } \\
\text { mung bean }\end{array}$ \\
\hline Article Info \\
\hline $\begin{array}{l}\text { Accepted: } \\
18 \text { April } 2020 \\
\text { Available Online: } \\
10 \text { May } 2020\end{array}$ \\
\hline
\end{tabular}

A field experiment was conducted during 2008-09 and 2009-10 at agriculture research farm of Rajeev Gandhi South Campus (RGSC) Barkacachha, Mirzapur of Banaras Hindu University to study the effect of graded levels of B application (0.0-3.0 $\left.\mathrm{kg} \mathrm{B} \mathrm{ha}^{-1}\right)$ with and without Rhizobium inoculation with recommended dose of fertilizer (RDF) on Yield, harvest index and total nutrient uptake by mung bean and fertility status of post harvest soil. The experiment was laid out under randomized block designed with three replications. It was found that application of graded levels of B fertilization with Rhizobium inoculation with RDF favorably influence grain, stover yield and harvest index as well as total $\mathrm{N}, \mathrm{P}, \mathrm{K}, \mathrm{S}$ and $\mathrm{B}$ uptake by mung been and also influence soil physicochemical environment and nutrient availability, such as $\mathrm{pH}$, organic carbon, available-N, $\mathrm{P}, \mathrm{K}, \mathrm{S}$ and $\mathrm{B}$ over the RDF alone applied in plot. Among all the treatment combination, the RDF and Rhizobium with $1.50 \mathrm{~kg} \mathrm{ha}^{-1} \mathrm{~B}$ application was found to be superior in improving yield, harvest index, nutrient uptake and also improve soil health over the other treatments.

\section{Introduction}

Micronutrients deficiencies have emerged as one of the major constraints in successful crop production in Indian soils. During the last three decades, micronutrient deficiencies have grown in both magnitude and extent due to increased use of high analysis fertilizers, high yielding crop varieties and increase in cropping intensity. This situation has aggregates a major constraint in reduction of productivity of cereal, oilseeds and pulses. Thus, there is an urgent need for correction of individual nutrient deficiency for arresting its further spread. Availability of micronutrients is closely related on physico-chemical nature of different soils type and plays an important role in sustaining higher crop productivity. 
Boron is one of the essential micronutrient for plant growth. Its deficiency is much more common in crops that are grown in soils containing higher amount of free carbonates, low organic matter, and high $\mathrm{pH}$ (Goldberg, et al., 2005). Fertilizer use in the country predominantly pertains to Nitrogen $(\mathrm{N})$ and Phosphorus (P). Potassium (K) use is confined to a crops and Boron use is negligible. Many introduced crop varieties are more susceptible to Boron deficiency (Chaudhry et al., 1976). Hence, soil conditions and agronomic practices are conducive to the incidence of Boron deficiency in plants.

The adequate management of Boron in soilplant system is usually difficult because the range between $\mathrm{B}$ deficiency and toxicity is relatively narrow. Thus, knowledge of the chemical behavior of $\mathrm{B}$ in the soil is particularly important. In order to recommend, the correct amount of Boron, it present in the soil and needs to the plants should be determined. The availability of it depends upon adsorption-desorption processes, which are influenced by various physicochemical properties of soils (Arora and Chahal, 2005).

The extent of it adsorption in soils depends on solution $\mathrm{pH}$, soil texture and mineral composition. The soil $\mathrm{pH}$ has been reported as the main factor affecting the $\mathrm{B}$ adsorption in the soil (Saltali et al., 2005; Soares et al., 2008). Pulse crops meet a major portion of their nitrogen requirement through biological fixation of atmospheric nitrogen. Seed treatment with crop specific strain of Rhizobium bacteria promotes N-fixation and improves crop yields by 10 to $20 \%$. Use of Rhizobium inoculants in pulse crops is an integral part of improved package of practices for pulses. It is also important for sustainability of our agricultural production system through biological nitrogen fixation process in soil and nutritional security of weaker section of the society, especially the children and lacting woman. Crops are strongly influenced by application of the nutrients. The magnitude of yield losses is due to nutrient deficiency and varies among the nutrients.

Since, micronutrient availability for the plant depends, among other factors, soil texture, organic matter and soil $\mathrm{pH}$. The response to added fertilizers application varied with soil type, soil moisture and management practices, besides the seasons in different areas particularly in rainfed agro-ecosystem. The major causes of Boron deficiency of in Indian soils are coarse textured, low $\mathrm{pH}$ and low organic matter content. In Boron deficient soil, both yield and quality of pulses are poor. The inclusion of this nutrient is essential in the fertilization scheduled. Thus Boron has become a key nutrient to increase productivity in B deficient light textured soil. Neglecting the B nutrient, will lead to a low yield, inferior crop quality and reduce efficiency of plant nutrient. The boron requirement of pulse is fairly high in comparison to oil seeds, cereal and millet crops (Murphy and Walsh, 1972).

\section{Materials and Methods}

The experiment was conducted at agriculture research farm of Rajeev Gandhi South Campus (RGSC), Barkacachha Banaras Hindu University during the 2008-09 and 2009-10. The experiment was laid out in Randomized Block Design (RBD) with three replications consisted of graded levels of boron application $i . e .0 .0,0.75,1.5$ and 3.0 $\mathrm{kg} \mathrm{B} \mathrm{ha}{ }^{-1}$ with and without Rhizobium application along with recommended dose of fertilizer. The soil of the experimental field was coarse in texture having $\mathrm{pH} 5.48$ and 5.53, organic carbon $3.8 \mathrm{~g} \mathrm{~kg}^{-1}$ and 3.5 , available $\mathrm{N} 162.54$ and $169.87 \mathrm{~kg}$ ha-1, 
available P 9.17 and $9.31 \mathrm{~kg}$ ha-1, available $\mathrm{K}$ 182.5 and $169.87 \mathrm{~kg}$ ha-1, available S 9.34 and $9.59 \mathrm{~kg}$ ha-1 and available B 0.32 and $0.29 \mathrm{mg} \mathrm{kg}-1$, respectively for year 2008-09 and 2009-10. The crop was harvested when it attained full maturity. Five plants were selected randomly from each plot at both pod picking and harvesting stages to serve as a substrate for analysis of concentration of nutrient contents in French bean pods and stover at pod picking stage and seed and stover at harvesting stage.

The selected samples were cleaned with tap water, dilute $\mathrm{HCl}$ (5 ml litre- 1 of water) and distilled water. The cleaned samples were separated into pods, seeds and stover and finally subject to oven drying at $65^{\circ} \mathrm{C}$, till the material exhibited constant weight (Tandon, 1993). The dried material was ground to powder in Wiley grinding mill. For estimating $\mathrm{N}$ concentration, the powdered material $(0.5$ g) was digested in concentrated $\mathrm{H} 2 \mathrm{SO} 4$ in presence of digestion mixture $\mathrm{K} 2 \mathrm{SO} 4$, FeSO4 and $\mathrm{CuSo} 4$ in the ratio of 10:1:0.5 with1 $\mathrm{g}$ Selenium powder (Jackson, 1973). The digest was cooled and diluted to $100 \mathrm{ml}$ with distilled water. $20 \mathrm{ml}$ of the digest was taken for $\mathrm{N}$ estimation.

For estimation of $\mathrm{P}, \mathrm{K}$, and $\mathrm{S}$ the powdered material $(0.5 \mathrm{~g})$ was digested in di-acid (HNO3 and $\mathrm{HClO} 4$ ) in the ratio of 9:4 (Jackson, 1973). The digested material was filtered and volume made up to $100 \mathrm{ml}$ with distilled water and $5 \mathrm{ml}$ of the digest was used for $\mathrm{P}, \mathrm{K}$ and $\mathrm{S}$ estimation respectively. For estimation of boron concentration the powdered material $(0.5 \mathrm{~g})$ was digested by dry ashing technique (Chapman and Pratt, 1961). The digested material was treated with $20 \% \mathrm{HCl}$ to dissolve it, filtered and volume made up to $25 \mathrm{ml}$ with distilled water. $1 \mathrm{ml}$ of aliquot was used for B estimation. Nutrient uptake at pod picking and harvesting stage was worked out by multiplying nutrient contents by respective dry matter contents. Soils were analysed by using standard procedures as described for available $\mathrm{N}$ (Subbiah and Asija, 1956), available phosphorus (Bray and Kurtz, 1945), available potassium (Jackson, 1973) and available sulphur (Williams and Steinbergs, 1959). Soil available B was extracted with boiling water in 1:2 suspensions for 5 minutes (Berger and Truog 1944).

Boron in soil and plant extracts was estimated using azomethine-H reagent as suggested by John et al., (1975). Total $\mathrm{N}$ in grain was determined by micro-Kjeldhal method. The significance of the difference among the treatment means was estimated by the least significant difference (LSD) test at 5\% level of probability (Gomez and Gomez, 1984).

\section{Results and Discussion}

\section{Crop yield and harvest index}

Grain yield (Table 1) of mung been was influenced significantly by the application $\mathrm{RDF}+$ Rhizobium $+1.5 \mathrm{~kg} \mathrm{~B} \mathrm{ha}^{-1}$ over RDF and RDF+ Rhizobium, RDF+0.75 kg boron ha ${ }^{-}$ ${ }^{1}$ during both the years. It was also found that different levels of boron (0.75-1.5 $\mathrm{kg} \mathrm{ha}^{-1}$ ) with Rhizobium inoculation increased significantly grain yield and decreased at 3.0 $\mathrm{kg} \mathrm{ha}{ }^{-1}$ of boron application in first year experiment. However linear increasing trend of grain yield was obtained with increasing in the level of boron from $0.75-3.0 \mathrm{~kg} \mathrm{ha}^{-1}$ without inoculation of Rhizobium in second year of field experiment.

The highest grain yield was obtained with conjugative use of Rhizobium $+1.5 \mathrm{~kg} \mathrm{~B} \mathrm{ha}{ }^{-1}$ along with RDF in both the years. The increase in grain yield was noticed upto $67.19,89.71$ per cent, respectively over control during both the years. Stover yield of mung bean was also influenced significantly 
by application of boron level with and without inoculation Rhizobium. The highest stover yield was recorded with RDF+ Rhizobium + $1.5 \mathrm{~kg} \mathrm{~B} \mathrm{ha}^{-1}$ of application over RDF, RDF+ Rhizobium during 2008-09 and 2009-10 except with RDF $+0.75 \mathrm{~kg} \mathrm{~B} \mathrm{ha}^{-1}$.It also clear from the table that level of boron with Rhizobium inoculation decreased stover yield at $3.0 \mathrm{~kg} \mathrm{~B} \mathrm{ha-1}$ of application. A linear increase in stover yield was obtained with an increase in the level of boron application upto increasing level of B at $3.0 \mathrm{~kg} \mathrm{~B} \mathrm{ha}^{-1}$ without inoculation of Rhizobium in both the years. Increase in grain and stover yield of mung bean was also reported by Singh et al., (2006) Valenciano et al., (2010) and Kumar et al., (2006).

\section{Total N, P, K, S and B uptake by mung bean}

Data pertaining to total N.P and K uptake by mung bean crop are depicted in table 2 . Results revealed that total N, P, ad K uptake by the crop was influenced significantly by the application of graded level of B with Rhizobium inoculation and close of N. P. K.

The total nitrogen uptake in mung bean was found to increase with increasing in the level of B upto the $1.5 \mathrm{~kg} \mathrm{~B} \mathrm{ha}^{-1}$ with Rhizobium inoculation and further increase in the $\mathrm{B}$ level @ $3.0 \mathrm{~kg} \mathrm{~B} \mathrm{ha}^{-1}$ reduced nitrogen uptake by crop. However, a linear increase of $\mathrm{N}$ uptake by crop was recorded with graded level of $\mathrm{B}$ application from 0.75 to $3.0 \mathrm{~kg} \mathrm{ha}^{-1}$ without Rhizobium inoculation during both the years of field experimentation.

The pooled higher total nitrogen uptake by crop (73.91 kg ha-1) was noticed with application of RDF+ Rhizobium $+1.5 \mathrm{Kg} \mathrm{B}$ $\mathrm{ha}^{-1}$ of application both the year over control (37.21 kg N ha- ${ }^{-1}$.). Application of RDF+ Rhizobium $+1.5 \mathrm{Kg} \mathrm{B} \mathrm{ha}{ }^{-1}$ also gave significant increase in the total phosphorus uptake by mung during both the years. The results further indicate that total phosphorus uptake by crop was found to increase with increasing in the level of B upto the $1.5 \mathrm{~kg} \mathrm{~B}$ $\mathrm{ha}^{-1}$ and declined with further increase in the boron level(3.0 kg ha-1) with Rhizobium inoculation Total phosphorus uptake by crop increased linearly with added B level from (0.75 to $3.0 \mathrm{~kg} \mathrm{~B} \mathrm{ha}{ }^{1}$ ) without Rhizobium inoculation in both the years.

The pooled highest of total potassium uptake (55.36 kg ha ${ }^{-1}$ ) by mung bean crop was noted with application of RDF+ Rhizobium $+1.5 \mathrm{Kg}$ $\mathrm{B} \mathrm{ha}{ }^{-1}$ with Rhizobium inoculation over rest of the treatments in both the years. Increase in the total $\mathrm{N}, \mathrm{P}$ and $\mathrm{K}$ uptake by the crop may be attributed to the increased availability of these nutrients in soil solution and better utilization by plant roots. It is evident from Table 3 total uptake of $S$ and $B$ is significantly affected by graded levels of Boron and highest uptake of $\mathrm{S}$ and $\mathrm{B}$ was noticed with $\mathrm{RDF}+$ Rhizobium $+1.5 \mathrm{Kg} \mathrm{B}$ ha $^{-}$ 1 .

Increase in grain, stover yields and Harvest Index of mung bean and also total uptake of $\mathrm{N}, \mathrm{P}, \mathrm{K}, \mathrm{S}$, and Boron by mung bean is directly related with adequate supply of $\mathrm{B}$ level in B deficient acidic upland red soils. The evidence suggests the role of $B$ in metabolic function (Hunt, 2003). Effects of B deprivation may exert multiple direct and indirect effects on membrane-bound processes. A direct role of $\mathrm{B}$ in maintaining membrane structure is likely through cis-diol complexation with glycoproteins, which are structural constituents of the plasma membrane (Goldbach et al., 2001; Brownet al., 2002). Effects of B deficiency, pointing to a structural role of $B$ in membrane stabilization, are an altered permeability for potassium (K) and sugars (Parr and Loughman, 1983; Goldbach, 1985; Cakmaket al., 1995). 


\section{Post-harvest soil properties}

\section{Soil pH, electrical conductivity and organic carbon in post-harvest soil}

Changes in $\mathrm{pH}, \mathrm{EC}$ and organic carbon due to application of boron and Rhizobium application in mung bean crops post-harvest soils in the years 2008-09 and 2009-10 in graded levels have presented in table 4 . It was observed that neither soil $\mathrm{pH}$ nor electrical conductivity of post-harvest soil significantly change by the application of boron and Rhizobium application in mung bean crops. Soil Organic Carbon also remained unaffected by the application of boron and Rhizobium application in mung bean crops, which could be due to the reason that mung bean is short duration crop, since no extra organic matter added in experimental plot and changes in Carbon stock is very slow process in cultivated lands. It is surmised that the boroncontaining oxides may have provided a precondition for absorption of elements, i.e., a condition to better utilize $\mathrm{Ca}, \mathrm{Mg}$ and other elements. Ren, et al., (2009) was found the non-significant correlation between boron and calcium and magnesium content in the soil with application of boron in soil.

\section{Availability of major nutrient in post- harvest}

Data pertaining to available nitrogen in postharvest soil is presented in table 5. A close examination on the data revealed that availability of nitrogen in post-harvest soil significantly increased with graded levels 0$3.0 \mathrm{~kg} \mathrm{ha}$ of boron and Rhizobium application in red soils of Mirzapur in both of the experimentation year. The highest availability of nitrogen recorded with $\mathrm{RDF}+$ Rhizobium $+1.50 \mathrm{~kg} \mathrm{ha}^{-1}$ application for both of experimentation year, which is significantly superior over the control (Recommended dose of fertilizer) and at par with rest of treatment. It was also observed that in second year of field experiment has greater nitrogen availability as compare to first year of experimentation. Increasing in nitrogen availability in post-harvest soil due the biological nitrogen fixation process, boron play an important role in biological nitrogen fixation it enhance the number of effective nodule (Bolãnos et al., 1994) and produce singling compound during the Rhizobia infection on roots of legume crop (Spaink, 2000). A critical data perusal on availability of phosphorus in post-harvest soil shows that availability of phosphorus in soil increased with application of graded levels of boron and Rhizobium application. The highest availability of phosphorus in experimentation year 2008-09 was recorded as $12.99 \mathrm{~kg} \mathrm{ha}^{-1}$, while in year 2009-10 it was $13.01 \mathrm{~kg} \mathrm{ha}^{-1}$ and pooled value is $13.00 \mathrm{~kg} \mathrm{ha}^{-1}$ recorded with application of $\mathrm{RDF}+$ Rhizobium +1.50 $\mathrm{kg} \mathrm{ha}^{-1}$, while minimum recorded with RDF for the both of experimentation. Application of $\mathrm{RDF}+$ Rhizobium $+1.50 \mathrm{~kg} \mathrm{ha}^{-1}$ significantly increasing the availability of phosphorus in red soils over the control(RDF) and Rhizobium inoculation alone while at par with rest of treatment. The increasing in availability of phosphorus due the enhancement in enzymatic activity (Phosphatase) in soil which is leads the release of phosphorus in soil (Bline et al., 2011).

The availability of potassium in post-harvest increased with increasing in levels of boron and Rhizobium inoculation in both of the experimentation, but it could not attained upto the levels of significance. The availability of NPK in RDF and Rhizobium with $1.50 \mathrm{~kg} \mathrm{ha}^{-1}$ boron application plots may be attributed to its biological nitrogen fixation and the red soil requirement of sufficient micronutrient as boron application, which the process of mineralization of organically bound micronutrients present in native soil. 
Table.1 Grain yield, stover yield and harvest index of mung bean as influenced by application of Boron and Rhizobium in red soils of Mirzapur

\begin{tabular}{|c|c|c|c|c|c|c|c|c|c|}
\hline \multirow[t]{2}{*}{ Treatments } & \multicolumn{3}{|c|}{ Grain Yield $\left(q\right.$ ha $\left.^{-1}\right)$} & \multicolumn{3}{|c|}{ StoverYield $\left(q\right.$ ha $\left.^{-1}\right)$} & \multicolumn{3}{|c|}{ Harvest Index $(\%)$} \\
\hline & 2008-09 & 2009-10 & Pooled & 2008-09 & 2009-10 & Pooled & 2008-09 & 2009-10 & Pooled \\
\hline RDF (Control) & 6.43 & 6.02 & 6.23 & 15.86 & 16.10 & 15.98 & 28.84 & 27.15 & 27.99 \\
\hline RDF + Rhizobium & 7.15 & 7.55 & 7.35 & 16.16 & 16.63 & 16.40 & 30.67 & 31.05 & 30.86 \\
\hline RDF + Rhizobium $+1.50 \mathrm{Kg} \mathrm{ha}^{-1} \mathrm{~B}$ & 10.75 & 11.42 & 11.09 & 18.62 & 20.56 & 19.59 & 36.60 & 35.67 & 36.13 \\
\hline RDF + Rhizobium $+3.00 \mathrm{Kg} \mathrm{ha}^{-1} \mathrm{~B}$ & 8.94 & 9.76 & 9.35 & 18.07 & 18.78 & 18.43 & 32.98 & 34.18 & 33.58 \\
\hline RDF $+0.75 \mathrm{Kg} \mathrm{ha}^{-1} \mathrm{~B}$ & 7.74 & 8.19 & 7.97 & 17.74 & 19.44 & 18.59 & 30.40 & 29.67 & 30.04 \\
\hline $\mathrm{RDF}+3.00 \mathrm{Kg} \mathrm{ha}^{-1} \mathrm{~B}$ & 9.32 & 10.16 & 9.74 & 18.56 & 20.42 & 19.49 & 33.30 & 33.29 & 33.30 \\
\hline SEm \pm & 0.63 & 0.80 & 0.29 & 0.61 & 0.75 & 0.28 & - & - & - \\
\hline $\mathrm{CD}(\mathbf{P}=\mathbf{0 . 0 5})$ & 1.85 & 2.34 & 0.60 & 1.94 & 2.19 & 0.57 & NS & NS & NS \\
\hline
\end{tabular}

RDF $=$ Recommended dose of fertilizer

Table.2 Total N, P and K uptake by mung bean crop as influenced by application of Boron and Rhizobium in red soils of Mirzapur

\begin{tabular}{|c|c|c|c|c|c|c|c|c|c|}
\hline \multirow[t]{2}{*}{ Treatments } & \multicolumn{3}{|c|}{ Total Nitrogen uptake(kg ha $\left.{ }^{-1}\right)$} & \multicolumn{3}{|c|}{ Total Phosphorus uptake(kg ha $\left.{ }^{-1}\right)$} & \multicolumn{3}{|c|}{ Total Potassium uptake $\left(\mathrm{kg} \mathrm{ha}^{-1}\right)$} \\
\hline & 2008-09 & 2009-10 & Pooled & 2008-09 & 2009-10 & Pooled & 2008-09 & 2009-10 & Pooled \\
\hline RDF (Control) & 37.77 & 36.65 & 37.21 & 4.47 & 4.30 & 4.39 & 29.81 & 37.91 & 33.86 \\
\hline RDF + Rhizobium & 43.11 & 44.47 & 43.79 & 5.51 & 6.24 & 5.87 & 34.88 & 44.86 & 39.87 \\
\hline $\begin{array}{l}\text { RDF + Rhizobium + } 0.75 \\
\text { Kg ha }^{-1} \text { B }\end{array}$ & 53.61 & 56.37 & 54.99 & 6.64 & 6.80 & 6.72 & 40.05 & 52.67 & 46.36 \\
\hline $\begin{array}{l}\text { RDF Rhizobium + } 1.50 \mathrm{Kg} \\
\mathrm{ha}^{-1} \mathrm{~B}\end{array}$ & 72.86 & 74.97 & 73.91 & 7.90 & 9.37 & 8.63 & 48.68 & 62.05 & 55.36 \\
\hline $\begin{array}{l}\text { RDF + Rhizobium + } 3.00 \\
\text { Kg ha }^{-1} \mathrm{~B}\end{array}$ & 59.31 & 60.22 & 59.76 & 6.63 & 6.52 & 6.58 & 41.33 & 52.20 & 46.77 \\
\hline $\mathrm{RDF}+0.75 \mathrm{Kg} \mathrm{ha}^{-1} \mathrm{~B}$ & 48.21 & 52.89 & 50.55 & 5.80 & 5.81 & 5.81 & 39.06 & 52.02 & 45.54 \\
\hline $\mathrm{RDF}+1.50 \mathrm{Kg} \mathrm{ha}^{-1} \mathrm{~B}$ & 55.46 & 58.01 & 56.74 & 6.90 & 6.87 & 6.88 & 43.23 & 54.90 & 49.07 \\
\hline $\mathrm{RDF}+3.00 \mathrm{Kg} \mathrm{ha}^{-1} \mathrm{~B}$ & 57.93 & 63.76 & 60.85 & 7.50 & 7.24 & 7.37 & 41.41 & 55.14 & 48.27 \\
\hline $\mathrm{SEm} \pm$ & 2.62 & 3.24 & 0.85 & 0.50 & 0.40 & 0.13 & 1.51 & 1.26 & 0.40 \\
\hline $\mathrm{CD}(\mathrm{P}=0.05)$ & 7.65 & 9.49 & 2.46 & 1.46 & 1.17 & 0.38 & 4.41 & 3.67 & 1.16 \\
\hline
\end{tabular}


Table.3 Total S and B uptake by mung bean as influenced by application of Boron and Rhizobium application in red soils of Mirzapur

\begin{tabular}{|c|c|c|c|c|c|c|}
\hline \multirow[t]{2}{*}{ Treatments } & \multicolumn{3}{|c|}{ Total Sulphur uptake $\left(\mathrm{kg} \mathrm{ha}^{-1}\right)$} & \multicolumn{3}{|c|}{ Total Boron $\left(\mathrm{g} \mathrm{ha}^{-1}\right)$} \\
\hline & 2008-09 & 2009-10 & Pooled & 2008-09 & 2009-10 & Pooled \\
\hline RDF (Control) & 4.59 & 4.09 & 4.34 & 215.92 & 195.15 & 205.53 \\
\hline RDF + Rhizobium & 5.04 & 5.23 & 5.13 & 240.02 & 219.92 & 229.97 \\
\hline RDF + Rhizobium + 0.75 Kg ha ${ }^{-1} \mathrm{~B}$ & 6.14 & 6.57 & 6.36 & 312.62 & 325.64 & 319.13 \\
\hline RDF + Rhizobium $+1.50 \mathrm{Kg} \mathrm{ha}^{-1} \mathrm{~B}$ & 7.98 & 8.20 & 8.09 & 636.76 & 638.20 & 637.48 \\
\hline RDF + Rhizobium + 3.00 Kg ha ${ }^{-1} \mathrm{~B}$ & 6.51 & 6.27 & 6.39 & 445.37 & 401.09 & 423.23 \\
\hline RDF+ 0.75 Kg ha ${ }^{-1} \mathrm{~B}$ & 5.06 & 5.31 & 5.19 & 239.14 & 252.05 & 245.60 \\
\hline $\mathrm{RDF}+1.50 \mathrm{Kg} \mathrm{ha}{ }^{-1} \mathrm{~B}$ & 5.58 & 5.68 & 5.63 & 417.67 & 425.32 & 421.49 \\
\hline $\mathrm{RDF}+3.00 \mathrm{Kg} \mathrm{ha}{ }^{-1} \mathrm{~B}$ & 5.91 & 6.63 & 6.27 & 440.75 & 453.78 & 447.26 \\
\hline SEm \pm & 0.34 & 0.22 & 0.08 & 75.09 & 65.83 & 20.38 \\
\hline $\mathrm{CD}(\mathrm{P}=\mathbf{0 . 0 5})$ & 1.00 & 0.64 & 0.24 & 219.72 & 192.62 & 59.05 \\
\hline
\end{tabular}

Table.4 Effect of Boron and Rhizobium application on pH, EC and organic carbon content of post-harvest experimental soil

\begin{tabular}{|c|c|c|c|c|c|c|c|c|c|}
\hline \multirow[t]{2}{*}{ Treatments } & \multicolumn{3}{|c|}{ pH } & \multicolumn{3}{|c|}{$\mathrm{EC}\left(\mathrm{dsm}^{-1}\right)$} & \multicolumn{3}{|c|}{ Organic carbon $\left(\mathrm{g} \mathrm{kg}^{-1}\right)$} \\
\hline & 2008-09 & 2009-10 & Pooled & 2008-09 & 2009-10 & Pooled & 2008-09 & 2009-10 & Pooled \\
\hline RDF(Control ) & 5.49 & 5.57 & 5.53 & 0.20 & 0.19 & 0.20 & 4.10 & 4.30 & 4.20 \\
\hline RDF + Rhizobium & 5.50 & 5.58 & 5.54 & 0.20 & 0.19 & 0.19 & 4.13 & 4.33 & 4.23 \\
\hline $\begin{array}{l}\text { RDF+Rhizobium + 0.75 Kg } \\
\text { ha }^{-1} \mathrm{~B}\end{array}$ & 5.49 & 5.58 & 5.54 & 0.19 & 0.18 & 0.18 & 3.90 & 4.10 & 4.00 \\
\hline $\begin{array}{l}\text { RDF+Rhizobium + } 1.50 \mathrm{Kg} \\
\mathrm{ha}^{-1} \mathrm{~B}\end{array}$ & 5.50 & 5.58 & 5.54 & 0.20 & 0.20 & 0.20 & 4.03 & 4.23 & 4.13 \\
\hline $\begin{array}{l}\text { RDF+Rhizobium }+3.00 \mathrm{Kg} \\
\text { ha }^{-1} \mathrm{~B}\end{array}$ & 5.50 & 5.58 & 5.54 & 0.18 & 0.17 & 0.18 & 3.97 & 4.17 & 4.07 \\
\hline RDF+0.75 Kg ha ${ }^{-1} \mathrm{~B}$ & 5.50 & 5.58 & 5.54 & 0.19 & 0.18 & 0.18 & 3.80 & 4.00 & 3.90 \\
\hline $\mathrm{RDF}+1.50 \mathrm{Kg} \mathrm{ha}^{-1} \mathrm{~B}$ & 5.50 & 5.58 & 5.54 & 0.19 & 0.18 & 0.19 & 4.10 & 4.30 & 4.20 \\
\hline $\mathrm{RDF}+3.00 \mathrm{Kg} \mathrm{ha}^{-1} \mathrm{~B}$ & 5.50 & 5.58 & 5.54 & 0.22 & 0.21 & 0.22 & 4.10 & 4.30 & 4.20 \\
\hline SEm \pm & - & - & - & - & - & - & - & - & - \\
\hline $\mathrm{CD}(0.05)$ & NS & NS & NS & NS & NS & NS & NS & NS & NS \\
\hline
\end{tabular}

$\mathrm{RDF}=$ Recommended dose of fertilizers 
Table.5 Effect of Boron and Rhizobium application on available N, P and K content of post-harvest experimental soil

\begin{tabular}{|c|c|c|c|c|c|c|c|c|c|}
\hline \multirow[t]{2}{*}{ Treatment } & \multicolumn{3}{|c|}{ Available Nitrogen(kg/ha) } & \multicolumn{3}{|c|}{ Available phosphorus (kg/ha) } & \multicolumn{3}{|c|}{ Available potassium (kg/ha) } \\
\hline & 2008-09 & 2009-10 & Pooled & 2008-09 & 2009-10 & Pooled & 2008-09 & 2009-10 & Pooled \\
\hline RDF(Control ) & 164.62 & 191.87 & 178.25 & 9.28 & 9.43 & 9.35 & 180.62 & 184.90 & 182.76 \\
\hline RDF + Rhizobium & 179.33 & 208.26 & 193.80 & 9.32 & 9.47 & 9.40 & 180.64 & 186.06 & 183.35 \\
\hline RDF+Rhizobium $+0.75 \mathrm{Kg} \mathrm{ha}^{-1} \mathrm{~B}$ & 199.01 & 208.97 & 203.99 & 10.90 & 10.89 & 10.90 & 185.90 & 179.23 & 182.57 \\
\hline RDF+Rhizobium + 1.50 Kg ha ${ }^{-1} \mathrm{~B}$ & 218.41 & 236.48 & 227.44 & 13.01 & 12.99 & 13.00 & 196.36 & 188.60 & 192.48 \\
\hline RDF + Rhizobium $+3.00 \mathrm{Kg} \mathrm{ha}^{-1} \mathrm{~B}$ & 201.37 & 194.77 & 198.07 & 11.30 & 11.31 & 11.30 & 191.88 & 183.14 & 187.51 \\
\hline RDF+0.75 Kg ha ${ }^{-1} \mathrm{~B}$ & 196.92 & 216.21 & 206.56 & 10.21 & 10.28 & 10.24 & 201.27 & 192.78 & 197.02 \\
\hline $\mathrm{RDF}+1.50 \mathrm{Kg} \mathrm{ha}^{-1} \mathrm{~B}$ & 201.94 & 231.34 & 216.64 & 11.15 & 11.13 & 11.14 & 189.57 & 189.87 & 189.72 \\
\hline $\mathrm{RDF}+3.00 \mathrm{Kg} \mathrm{ha}^{-1} \mathrm{~B}$ & 198.42 & 194.44 & 196.43 & 10.75 & 10.85 & 10.80 & 187.47 & 183.96 & 185.72 \\
\hline SEm \pm & 10.49 & 5.79 & 2.45 & 0.71 & 0.68 & 0.20 & - & - & - \\
\hline $\mathrm{CD}(0.05)$ & 30.69 & 16.94 & 7.08 & 2.09 & 1.98 & 0.58 & NS & NS & NS \\
\hline
\end{tabular}

Table.6 Effect of Boron and Rhizobium application on available S and B content of post-harvest experimental soil

\begin{tabular}{|c|c|c|c|c|c|c|}
\hline \multirow[t]{2}{*}{ Treatment } & \multicolumn{3}{|c|}{ Available sulphur (mg/kg) } & \multicolumn{3}{|c|}{ Available Boron (mg/kg) } \\
\hline & 2008-09 & 2009-10 & Pooled & 2008-09 & 2009-10 & Pooled \\
\hline RDF(Control ) & 9.71 & 9.84 & 9.78 & 0.310 & 0.313 & 0.313 \\
\hline RDF + Rhizobium & 10.60 & 10.77 & 10.68 & 0.327 & 0.340 & 0.340 \\
\hline RDF + Rhizobium $+0.75 \mathrm{Kg} \mathrm{ha}^{-1} \mathrm{~B}$ & 11.45 & 11.62 & 11.53 & 0.360 & 0.370 & 0.370 \\
\hline RDF + Rhizobium $+1.50 \mathrm{Kg} \mathrm{ha}^{-1} \mathrm{~B}$ & 13.54 & 14.02 & 13.64 & 0.413 & 0.433 & 0.433 \\
\hline $\mathrm{RDF}+$ Rhizobium $+3.00 \mathrm{Kg} \mathrm{ha}^{-1} \mathrm{~B}$ & 12.21 & 12.36 & 12.29 & 0.390 & 0.377 & 0.377 \\
\hline RDF+0.75 Kg ha ${ }^{-1} \mathrm{~B}$ & 11.56 & 11.67 & 11.61 & 0.360 & 0.353 & 0.353 \\
\hline $\mathrm{RDF}+1.50 \mathrm{Kg} \mathrm{ha}^{-1} \mathrm{~B}$ & 12.09 & 12.19 & 12.14 & 0.360 & 0.393 & 0.393 \\
\hline $\mathrm{RDF}+3.00 \mathrm{Kg} \mathrm{ha}^{-1} \mathrm{~B}$ & 12.46 & 12.59 & 12.51 & 0.407 & 0.407 & 0.407 \\
\hline SEm \pm & 0.62 & 0.59 & 0.18 & 0.021 & 0.024 & 0.007 \\
\hline $\mathrm{CD}(0.05)$ & 1.81 & 1.74 & 0.52 & 0.062 & 0.071 & 0.019 \\
\hline
\end{tabular}


The increased availability is also due to the formation of organic chelate of high stability with organic legends, which have lower susceptibility to adsorption, fixation and precipitation in the soil (Kushwaha et al., 2009).

\section{Available Sulphur and boron in post- harvest soil}

Data pertaining available sulphur and boron presented in table 6 . It is evident from the availability of sulphur in post-harvest soil increased with adding of boron and Rhizobium, highest sulphur recorded with the application of RDF+ Rhizobium $+1.5 \mathrm{~kg} \mathrm{~B}$ ha 1, 13.54 and $14.02 \mathrm{mg} \mathrm{kg}^{-1}$, respectively for the year of 2009-09 and 2009-10 with the pooled value $13.64 \mathrm{mg} \mathrm{kg}^{-1}$. Application of $\mathrm{RDF}+$ Rhizobium $+1.5 \mathrm{~kg} \mathrm{~B} \mathrm{ha}^{-1}$ improvement in availability of sulphur over the control and at par with rest of treatment for the both year of experiment. On pooled base RDF+ Rhizobium $+1.5 \mathrm{~kg} \mathrm{~B} \mathrm{ha}^{-1}$ proved significantly improve over rest of treatment. This is might be due change in microbial activity in soil which is influence the enzymatic activity in soil (Bilen et al., 2011).

The availability of boron in post-harvest soil significantly increased with increasing in levels of boron and application of Rhizobium. The highest availability of boron recorded in application of RDF+Rhizobium $+1.5 \mathrm{~kg}$ boron $\mathrm{ha}^{-1}, 0.413$ and $0.433 \mathrm{mg} \mathrm{kg}^{-1}$, respectively for the year of 2008-09 and 2009-10 with the pooled value $0.423 \mathrm{mg} \mathrm{kg}^{-1}$. The application of RDF+ Rhizobium+ $1.5 \mathrm{~kg} \mathrm{~B} \mathrm{ha}{ }^{-1}$ has significantly improvement over the RDF and RDF+ Rhizobium and at par with rest of treatment.

The increasing of availability of boron might be due to application of external boron in red soils. This could be due to more vegetative growth and root growth, which release root exudates resulted in increased boron availability in soil (Hellal, et al., 2009). The results of the investigation are in consonance with the findings of Diab (1992) found a positive relationship between $B$ and the concentration of $\mathrm{B}, \mathrm{N}, \mathrm{P}$ and $\mathrm{K}$ in wheat plants.

On the basis of above finding we can say inclusion of boron fertilization in mung bean with Rhizobium inoculation enhance the Crop yield, harvest index total nutrient uptake and availability of $\mathrm{N}, \mathrm{P}, \mathrm{K}, \mathrm{S}$ and $\mathrm{B}$ in red soils of Mirzapur. Therefore, it is common recommendation for red soils of Mirzapur the application of RDF+ Rhizobium $+1.5 \mathrm{~kg} \mathrm{~B}$ $\mathrm{ha}^{-1}$ is beneficial for build the soil health.

\section{References}

Arora, S. and Chahal, D. S. (2005). Available boron content in some benchmark soils of Punjab under different moisture regimes in relation to soil characteristics. Agropedology, 15 (2), 90-94.

Berger, K. C. and Truog, E. (1944). Extraction and determination of plant available B in soil. Soil Science 57, 3235.

Bilen, S., Murat, B. and Sougata B. (2011). The effects of boron management on soil microbial population and enzyme activities. African Journal of Biotechnology. 10(27), 5311-5319.

Bolaños L, Cebrián A, Redondo-Nieto M, Rivilla R, Bonilla I (2001). Lectin-like glycoprotein PsNLEC-1 is not correctly glycosylated and targeted in boron deficient pea nodules. Mol Plant Microbe Interact .14: 663-670.

Bray, RH. and Kurtz, L.T. (1945) Determination of total, organic and available forms of phosphorus in soils. Soil Science. 59, 39-45.

Bremner, J.M. and C.S. Mulvaney (1982). 
Total nitrogen, In: Methods of Soil Analysis, Part 2, $2^{\text {nd }}$ Ed., Page, A.L. Miller, R.H. and Keeney, D.R. Amer. Soc. Agron. Inc., Madi., Wis., USA. 599-622.

Brown, P.H., Bellaloui, N., Wimmer, M.A., Bassil, E.S., Ruiz, J., Hu, H., Pfeffer, H. and Dannel, F.V. Boron in plant biology. Plant Biol., 4: 205-223, 2002.

Cakmak, I.,Kurz, H.,Marschner, H. Shortterm effects of boron, germanium and high light intensity on membrane permeabilityin boron deficient leaves of sunflower, Physiol. Plant.,95: 1118,1995

Chapman HD, Pratt PF (1961). Methods of analysis for soils, plants and water. University of California, Division Agricultural Science, Manual, pp. 25-53 Chaudhry, F. M., Latif, A., Rashid, A. \& Alam, S. M. (1976). Response of the rice varieties to field application of micronutrient fertilizers. Pakistan Journal of Industrial and Scientific Research, 19, 134-139.

Dell B., Huang L. (1997): Physiological response of plants to low boron. Plant and Soil. 193: 103-120.

Diab, M. (1992). Boron requirement of wheat and effect on the growth and nutrients $\mathrm{B}, \mathrm{N}, \mathrm{P}$ and $\mathrm{K}$ content. Egypt J. Appl. Sci., 7 (8): 412-421.

Goldbach, H. E. (1985). Influence of boron nutrition on net uptake and efflux of $32 \mathrm{P}$ and 14C-glucose in Helianthus annuиs roots and cell cultures of Daucus carota, J. Plant Physiol., 118: 431-438.

Goldbach, H.E., Yu, Q., Wingender, R., Schulz, M., Wimmer, M., Findeklee, P., Baluska, F. (2001). Rapid response reactions of roots to boron deprivation, J. Plant Nutr. Soil Sci., 164: 173-181.

Goldberg, S., D.L. Corwin, PJ. Shouse, and D.L. Suarez. 2005. Prediction of boron adsorption by field samples of diverse textures. Soil Science Society of America Journal . 69:1379-1388.

Goldberg, S., M. L. Scott and D.L. Suarez (2000). Predicting boron adsorption by soils using soil chemical parameters in the constant capacitance model. Soil Sci. Soc. Am. J., 64: 1356-1363.

Gomez, K.A. and A. A. Gomez (1984). Statistical Procedures for Agricultural Research. Int. Rice Res. Inst., John Wiley \& Sons, NY.

Hellal, F.A., Taalab, A. S. and Safaa, A. M. (2009). Influence of nitrogen and boron nutrition on nutrient balance and Sugar beet yield grown in calcareous Soil. Ozean Journal of Applied Sciences, 2(1): $1-10$.

Hunt, C. D (2003). Dietary boron: An overview of the evidence for its roles in immune function. Trace Elem. Exp. Med. 16, 291-306.

Jackson, M. L. (1973). Soil Chemical Analysis, Prentice Hall of India Pvt. Ltd., New Delhi.

John, M.K., Chuah, H.H. and Neufeld, J.H. (1975) Application of improved azomethine- $\mathrm{H}$ method to the determination of boron in soils and plants. Analytica Letters, B, 559-568.

Kumar, A., Prasad, S. and Kumar, S.B. (2006). Effect of boron and sulphur on performance of gram (Cicer arietinum), Indian Journal of Agronomy, 51(1): 5759.

Kushwaha Ajit Kumar, Surendra Singh and R.N. Singh (2009). Available Nutrients and Response of Lentil (Lense esculenta) to Boron Application in Rainfed Upland Soils of Ranchi. Journal of the Indian Society of Soil Science, 57(2) 219-222.

Murphy. LS. and Walsh. L.M. (1997). In: Micronutrient in Agriculture Correction of micronutrient Deficiency with Fertilizers (Mortved Madison ed.) Am Soc. Agron. 47-387. 
Parr, A. and Loughman, B.C.(1983)Boron membrane functions in plants. In: Metals and Micronutrients: Uptake and utilization by plants, edited by Robb, D.A. and Pierpoint, W.S. London: Academic Press, 87-107.

Ren, L., Zhu, D., Cui, J., Liao, S., Geng, M., Zhou, W., and Hamilton, D. (2009) Plant availability of boron doped on iron and manganese oxides and its effect on soil acidosis. Geoderma 151: 401-406

Saltali, K., A.V. Bilgili, C. Tarakcioglu, and A. Durak. (2005). Boron adsorption in soils with different characteristics. Asian Journal of Chemistry 17:24872494.

Singh, R.N., Singh, S. and Kumar, B. Interaction Effect of Sulphur and Boron on Yield, Nutrient Uptake and Quality Characters of Soybean (Glycine max L. Merill) Grown in Acidic Upland Soil, Journal of the Indian Society of Soil Science, 54(4): 516-518,2006

Soares, M.R., J.C. Casagrande, and L.R.F. Alleoni. (2008). Adsorção de boro em solos ácricos em função da variação do $\mathrm{pH}$. Revista Brasileira de Ciencias do Solo 32:111-120.

Spaink H.P. (2000) Root nodulation and infection factors produced by rhizobial bacteria, Annu. Rev. Microbiol. 54, 257-288.

Subbiah, B.V. and Asija, G.L. (1956) A rapid procedure for estimation of available nitrogen in soils. Current Science 25, 259-260.

Tandon HLS (1993). Methods of Analysis of soil, plant, water and fertilizer. Water and Fertilizers, 1-48, 1993.

Valenciano, J. B., Boto, J. A. and Marcelo, V. Response of chickpea (Cicer arietinum L.) yield to zinc, boron and molybdenum application under pot conditions, Spanish Journal of Agricultural Research. 8(3): 797-807, 2010.

Williams, C.H. and Steinbergs, A. (1959) Soil sulphur fractions and chemical !ndices of available sulphur in some Australian soils. Australian Journal of Agricultural Research 10, 340-352.

\section{How to cite this article:}

Mishra, P. K., Surendra Singh, R. Verma and Verma, S. S. 2020. Effect of Rhizobium and Boron Application on Yield of Mung Bean, Nutrients Uptake and Fertility Status Grown in Red Soils of Mirzapur. Int.J.Curr.Microbiol.App.Sci. 9(05): 2493-2503. doi: https://doi.org/10.20546/ijcmas.2020.905.285 